\title{
Effects of Chronic Disease Control Club on Physical Activity, Anxiety, and Blood Sugar Level: A Path Analysis Evidence
}

\author{
Fajar Alam Putra'), Dono Indarto'), Ruben Dharmawan²) \\ 1)Masters Program in Public Health, Universitas Sebelas Maret \\ 2)Faculty of Medicine, Universitas Sebelas Maret
}

\begin{abstract}
Background: Diabetes mellitus (DM) is a serious chronic disease with a tendency to worsen. The number of DM cases worldwide in 2015 was 415 million people and is expected to increase by 642 million cases in 2040. Indonesia ranks 7th in the world with 10 million DM cases in 2015, around 90\% of which are Diabetes Mellitus Type 2. This study aimed to determine the effects of chronic disease control club on physical activity, anxiety, and blood sugar level.

Subjects and Method: This was a cross sectional study conducted at Sukoharjo health center, Sukoharjo, Central Java, from August to September 2018. A sample of 245 type 2 DM patients was selected for this study. The independent variables were physical activity, anxiety, chronic disease control club, and complications. Data were collected using HARS, physical activity, complication and club activitiesquestionnaires. Data were analyzed by using path analysis.

Results: Anxiety directly increased with complication $(b=12.55 ; 95 \% \mathrm{CI}=111.98$ to 13.90 ; $\mathrm{p}<0.001)$. Anxiety directly decreased with chronic disease control club $(\mathrm{b}=-3.29 ; 95 \% \mathrm{CI}=-4.72$ to $-1.85 ; \mathrm{p}<0.001)$. Fasting blood sugar directly increased with anxiety $(b=2.78 ; 95 \% \mathrm{CI}=1.32$ to 4.24; $\mathrm{p}<0.001)$ and complication $(\mathrm{b}=33.14 ; 95 \% \mathrm{CI}=8.40$ to $57.87 ; \mathrm{p}=0.009)$. Fasting blood sugar directly decreased with physical activity $(\mathrm{b}=-15.12 ; 95 \% \mathrm{CI}=-19.89$ to $-10.35 ; \mathrm{p}<0.001)$ and chronic disease control club $(b=-30.14 ; 95 \% \mathrm{CI}=-48.80$ to $-11.48 ; \mathrm{p}=0.002)$.

Conclusion: Anxiety directly increases with complication. Anxiety directly decreases with chronic disease control club. Fasting blood sugar directly increases with anxiety and complication. Fasting blood sugar directly decreases with physical activity and chronic disease control club.
\end{abstract}

Keywords: blood sugar level, physical activity, anxiety, chronic disease control club

Correspondence:

Fajar Alam Putra. Masters Program in Public Health, Universitas Sebelas Maret. Jl. Ir. Sutami 36 A, Surakarta 57126, Central Java. Email: bolodewe88@gmail.com

\section{BACKGROUND}

Noncommunicable diseases (NCDs) or also known as chronic diseases tend to have a long duration and are the result of a combination of genetic, physiological, environmental and behavioral factors. NCDsis often associated with various risk factors such as environmental pollution due to the use of various toxic chemicals combined with life style behaviors that cause people to be exposed to "unnatural" environmental conditions. Genetically, the interactive correlation between humans and their environment can cause changes in the genetic structure that draws up life. The main types of NCDs are cardiovascular disease (such as heart attacks and stroke), cancer, chronic respiratory diseases (such as chronic obstructive pulmonary disease and asthma) and diabetes. NCDs generally affect low and middle income people in a country. More than three-quarters of the 31 million global NCD deaths occur (WHO, 2017). Noncommunicable diseases are chronic diseases that cannot be transmitted from one person to another (Basic Health Research (Riskesdas), 2013). WHO estimates that deaths from non-communicable diseases will con- 
Journal of Health Promotion and Behavior (2019), 4(3): 137-144

https://doi.org/10.26911/thejhpb.2019.04.02.06

tinue to increase throughout the world. In 2030, globally, regionally, and nationally it is projected that an epidemiological transition will occur from communicable diseases to non-communicable diseases, an estimated proportion of deaths to $69 \%$ and 52 million deaths per year due to non-communicable diseases (Central Java Health Office, 2014).

An increase in non-communicable diseases has a negative impact on the economy and productivity. The economic impact is closely related to poverty, both in the form of direct costs such as medical and rehabilitation costs or indirect costs such as loss of income due to illness, disability or early death and for labor productivity, working hours, and contributing to the occurrence of early retirement and disability, including permanent disability (Central Java Health Office, 2014).

In 2017, Indonesia ranked seventhin the world, reaching 10 million people with diabetes (IDF, 2017). The World Health Organization (WHO) estimates the prevalence of diabetes mellitus in Indonesia is increased by $154 \%$ from 2000 to 2030 . According to the 2013 Regional Health Research (RISKESDAS), the prevalence rate of people with diabetes is $6.8 \%$ in Indonesia. The number of cases of insulindependent Diabetes Mellitus in Central Java Province in 2013 was 9,376 cases. In 2014, the health centers reported that there were 5,413 cases, a slight increase compared to 2013 with 5,052 DM cases. Most cases were reported by Sukoharjo Health Center. While most of the case reporting from the hospital came from Dr. OEN Solo Baru (859) Sukoharjo District General Hospital (645 cases) and Islam/ Yarsis Hospital (334 cases). Mojolaban area is one of the biggest contributors among the Health centers and other hospitals, because there were 405 cases with DM Type II in Mojolaban Health Centerin 2014.

Uncontrolled diabetes mellitus is at high risk for both micro and macrovascular complications. There are 3 types of macrovascular complication that commonly develop in people with diabetes they are coronary artery disease (CAD), cerebral vascular disease, and peripheral vascular disease (PVD). Microvascular complications such as diabetic retinopathy, diabetic nephropathy, and diabetic neuropathy. This will certainly cause a high cost of health services (Health Insurance (ASKES), 2012).

Since 2010 PT. Askes (Persero) as a health insurance service provider company implemented the Chronic Disease Management Program (Prolanis). This program is a chronic disease management with integrated promotive and preventive actions. One of the chronic diseases that are treated is type 2 diabetes mellitus (InfoAskes, 2010). In the health care strategy for people with diabetes, primary health care is placed as the spearhead so that the role of the Health center becomes very important, including in the health center of Sukoharjo.

Diabetes mellitus is a disease with a tendency to increase from year to year. Dietary changes, physical activity and anxiety are risk factors for diabetes mellitus. Gymnastics and physical activity are recommended for both the pre elderly (45 years) and the elderly (65 years and over) because they inhibit the aging process (degenerative). Lack of exercise can cause hypertension due to decreased cardiac output and stiffness of blood vessels so that the blood pumping to the heart is reduced and blood flow is blocked (Setiawan et al, 2014). The age group of 45 years or more, who has a history of DM is an age group at risk of suffering from DM, as well as an people with unhealthy eating is a group that is at risk of suffering from DM, so in this 
community group it is recommended to conduct screening test especially for early detection of the symptoms of prediabetes and diabetes (Zahtamal et al, 2007). Patients with type 2 diabetes mellitus in Simpur, Bandar Lampung Health Center in 2015 were 125 people and there was a significant correlation between health insurance program participation with compliance with the treatment for patients with type 2 diabetes mellitus (Shaqina, 2016).

\section{SUBJECTS AND METHOD \\ 1. Study Design \\ This was an analytic observational study with a cross sectional design. This study was conducted at Mojolaban, Polokarto, and Bendosari Health Centers, Sukoharjo, Central Java, from July to October 2018.}

\section{Population and samples}

The total sample was 245 cases of type 2 diabetes was selected for this study.

\section{Study Variables}

The dependent variable was fasting blood sugar. The independent variables were physical activity, anxiety, chronic disease control club, and complications.

4. Operational Definition of Variables Physical training was defined as physical activity that was carried out regularly, measured, and continuously so as to improve physical fitness (WHO, 2016). The data were collected by questionnaire (intensity, frequency, and duration). The measurement scale was continous.

Anxiety. Anxiety was defined as monitoring anxiety of people with DM about the disease and its complications. The data were collected by HRS-A questionnaire. The measurement scale was continous.

Chronic disease control club was defined as gymnastics activities carried out in groups. The measurement scale was continous.
Blood glucose was defined as sugar found in blood formed from carbohydrates in food and stored as glycogen in the liver and skeletal muscle after fasting for 8 hours. The data were measured by glucometer. The measurement scale was continous.

Complication was defined as current illness that was a result of long-term complications of DM. The data were measured by questionnaire. The measurement scale was categorical.

Smoking habit was defined as smoking cigarettes that could cause smoke that could be inhaled by others. Data were collected by questionnaire. The measurement scale was categorical.

Body mass index (BMI) was defined as the ratio of body weight and height measured from head to toe. Body weight was measured by weight scale. Body height was measured by microtoise. The measurement scale was continous.

\section{Data Analysis}

Univariate was conducted to describe sample characteristics. Bivariate analysis was conducted by Pearson correlation. Multivariate analysis was conducted by path analysis run on Stata 13 .

\section{Ethics of the Study}

Ethics of the study were informed consent, anonymity, and confidentiality.

\section{RESULTS}

\section{Sample Characteristics}

From Table 1, the majority of respondents were female and the average age of respondents was $58.46 \pm 9.82$ years. For the level of education, the percentage of primary, secondary and higher education was almost the same $\pm 25 \%$. From the nutritional status, respondents had an average BMI of $22.78 \pm 3.20 \mathrm{~kg} / \mathrm{m}^{2}$, and $45.3 \%$ was overweight category. $64 \%$ of respondents did not have a history of DM in their family members and in general, respondents did
} 
Journal of Health Promotion and Behavior (2019), 4(3): 137-144

https://doi.org/10.26911/thejhpb.2019.04.02.06

not smoke. Average physical exercise was 7.17. The average of anxiety was 12.16 .

95.1\%. Those who had complications were $27.8 \%$.

Respondents who were active in club were

Table 1. Sample characteristics

\begin{tabular}{|c|c|c|c|}
\hline Characteristics & Mean \pm SD & $\mathbf{n}$ & $\%$ \\
\hline \multicolumn{4}{|l|}{ Sex } \\
\hline Male & & 85 & 34.7 \\
\hline Female & & 160 & $65 \cdot 3$ \\
\hline \multicolumn{4}{|l|}{ Level of education } \\
\hline Senior High School & & 53 & 21.6 \\
\hline Junior High School & & 59 & 24.1 \\
\hline Senior High School & & 70 & 28.6 \\
\hline Associate's degree or higher & & 63 & 25.7 \\
\hline Age (years) & $58.46 \pm 9.82$ & & \\
\hline $\mathrm{BMI}\left(\mathrm{kg} / \mathrm{m}^{2}\right)$ & $22.78 \pm 3.20$ & & \\
\hline Underweight & & 16 & 6.5 \\
\hline Normal & & 118 & 48.2 \\
\hline Overweigt & & 111 & $45 \cdot 3$ \\
\hline \multicolumn{4}{|l|}{ Family History } \\
\hline No & & 157 & 64.1 \\
\hline Yes & & 88 & $35 \cdot 9$ \\
\hline \multicolumn{4}{|l|}{ Smoking habit } \\
\hline Non-smoker & & 225 & 91.8 \\
\hline Smoker & & 20 & 8.2 \\
\hline Physical training & $7.17 \pm 0.496$ & & \\
\hline Anxiety Level & $12.16 \pm 7.39$ & & \\
\hline \multicolumn{4}{|l|}{ Club activity } \\
\hline Non-active & & 12 & $4 \cdot 9$ \\
\hline Active & & 233 & 95.1 \\
\hline \multicolumn{4}{|l|}{ Complications } \\
\hline No & & 177 & 72.2 \\
\hline Yes & & 68 & 27.8 \\
\hline
\end{tabular}

\section{Bivariate Analysis}

Tabel 2. Bivariate analysis on the factors associated with fasting blood sugar level

\begin{tabular}{lcc}
\hline Independent Variable & $\mathbf{r}$ & $\mathbf{p}$ \\
\hline Physical activity & -0.62 & $<0.001$ \\
Anxiety & 0.62 & $<0.001$ \\
Prolanist club activeness & -0.45 & $<0.001$ \\
Complications & 0.59 & $<0.001$ \\
Body Mass Index & 0.04 & 0.565 \\
\hline
\end{tabular}

The Pearson correlation test was used to analyze the correlation between physical activity, anxiety, club activeness, complications and BMI with fasting blood sugar. Table 2 shows that physical activity $(\mathrm{r}=-0.62 ; \mathrm{p}<0.001)$ and club activeness $(\mathrm{r}=-0.43 ; \mathrm{p}<0.001)$ were strongly asso- ciated with fasting blood sugar and were statistically significant.

Anxiety $(\mathrm{r}=0.62 ; \mathrm{p}<0.001)$ and complication $(\mathrm{r}=0.59 ; \mathrm{p}<0.001)$ were positively related to fasting blood sugar.

BMI was positively correlated with fasting blood sugar but it was statistically not significant $(r=0.04 ; p=0.565)$. 
3. Multivariate Analysis

Figure 1 illustrated path analysis model with estimation. Figure 1 showed 3 endo- genous variables and 2 exogenous variables.

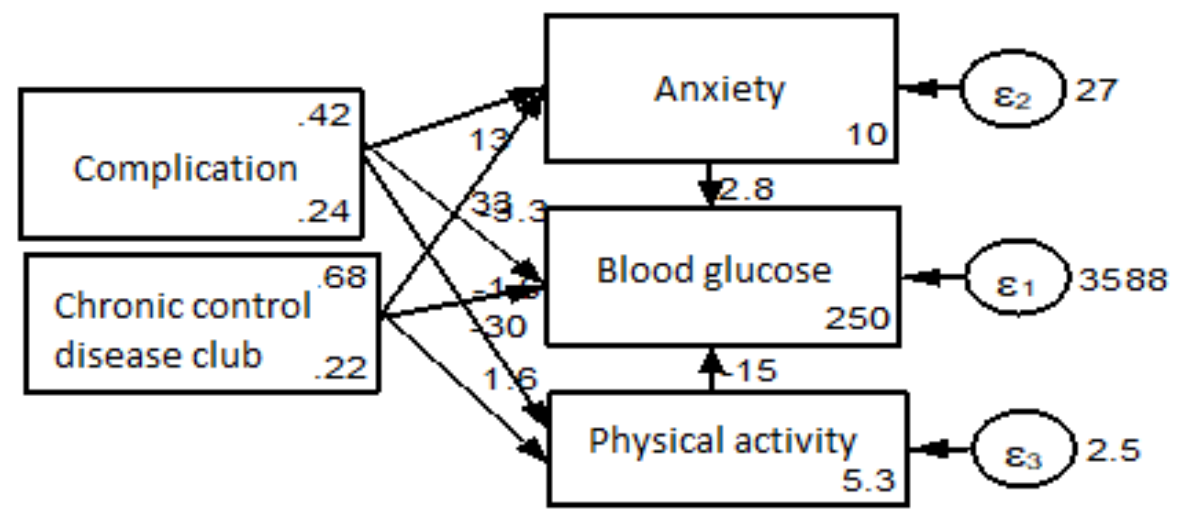

Figure 1. Structural model of path analisis with estimation

Table 3. The Results of Path Analysis

\begin{tabular}{|c|c|c|c|c|c|c|}
\hline \multirow{2}{*}{ DependentVariabe } & & \multirow{2}{*}{$\begin{array}{l}\text { Independent } \\
\text { Variabel }\end{array}$} & \multirow[b]{2}{*}{ b } & \multicolumn{2}{|c|}{ 95\% CI } & \multirow[b]{2}{*}{$\mathbf{p}$} \\
\hline & & & & $\begin{array}{l}\text { Lower } \\
\text { limit }\end{array}$ & $\begin{array}{l}\text { Upper } \\
\text { limit }\end{array}$ & \\
\hline \multicolumn{7}{|l|}{ Direct effect } \\
\hline \multirow[t]{3}{*}{ Anxiety } & $\leftarrow$ & Complication & 12.55 & 111.98 & 13.90 & $<0.001$ \\
\hline & $\leftarrow$ & Chronic disease & -3.29 & & & \\
\hline & & control club & & -4.72 & -1.85 & $<0.001$ \\
\hline \multirow{4}{*}{ Fasting blood sugar } & $\leftarrow$ & Anxiety & 2.78 & 1.32 & 4.24 & $<0.001$ \\
\hline & $\leftarrow$ & Physical activity & -15.12 & -19.89 & -10.35 & $<0.001$ \\
\hline & $\leftarrow$ & Complications & 33.14 & 8.40 & 57.87 & 0.009 \\
\hline & $\leftarrow$ & $\begin{array}{l}\text { Chronic disease } \\
\text { control club }\end{array}$ & -30.14 & -48.80 & -11.48 & 0.002 \\
\hline \multicolumn{7}{|l|}{ Indirect effect } \\
\hline \multirow[t]{2}{*}{ Physical Activity } & $\leftarrow$ & Complications & -1.55 & -1.96 & -1.14 & $<0.001$ \\
\hline & $\leftarrow$ & $\begin{array}{l}\text { Chronic disease } \\
\text { control club }\end{array}$ & 1.55 & 1.11 & 1.99 & $<0.001$ \\
\hline \multicolumn{7}{|c|}{$\begin{array}{l}\text { N Observation }=245 \\
\text { Log likehood }=-2887.64\end{array}$} \\
\hline \multicolumn{2}{|c|}{$\mathrm{AIC}=5803.29$} & $\mathrm{CFI}=0.99$ & & & & \\
\hline $\mathrm{BIC}=5852.30$ & & TLI $=0.99$ & & & & \\
\hline
\end{tabular}

Table 4 shows the results of path analysis. Anxiety directly increased with complication $(b=12.55 ; 95 \% \mathrm{CI}=111.98$ to 13.90; $\mathrm{p}<0.001)$. Anxiety directly decreased with chronic disease control club $(\mathrm{b}=$ -3.29 ; $95 \% \mathrm{CI}=-4.72$ to $-1.85 ; \mathrm{p}<0.001$ ).

Fasting blood sugar directly increased with anxiety $(b=2.78 ; 95 \% \mathrm{CI}=1.32$ to $4.24 ; \mathrm{p}<0.001)$ and complication $(\mathrm{b}=$ 33.14; $95 \% \mathrm{CI}=8.40$ to 57.87 ; $\mathrm{p}=0.009$ ).

Fasting blood sugar directly decreased with physical activity $(b=-15.12 ; 95 \%$
$\mathrm{CI}=-19.89$ to $-10.35 ; \mathrm{p}<0.001)$ and chronic disease control club $(b=-30.14 ; 95 \%$ $\mathrm{CI}=-48.80$ to $-11.48 ; \mathrm{p}=0.002)$.

\section{DISCUSSION}

1. The correlation between physical activity and fasting blood sugar

From the results of the analysis, there is a positive correlation between physical activity and a decrease in fasting blood sugar. Patients who often do physical activity will 
Journal of Health Promotion and Behavior (2019), 4(3): 137-144

https://doi.org/10.26911/thejhpb.2019.04.02.06

reduce fasting blood sugar $(\mathrm{b}=-15.12 ; \mathrm{p}$ $<0.001)$.

Physical activity carried out by a person can increase the sensitivity of insulin receptors so that glucose can be converted into energy through metabolism. One of the benefits of physical activity is that it can reduce blood sugar level in people with diabetes mellitus. It also can prevent obesity, complication, and lipid disorder, and increased blood pressure (Ilyas, 2011).

Physical activity carried out by someone will affect their blood sugar level. The increased use of glucose by the muscles will increase when a person performs high physical activity. That is because endogenous glucose will be increased to keep the blood sugar level in balance. Under normal circumstances, the balance of blood sugar level can be achieved by various mechanisms of the nervous system, glucose regulation and hormonal states (Kronenberg, 2008).

Another theory stated that physical activity is directly related to the speed of recovery of muscle blood sugar. When physical activity is carried out, the muscles in the body will react using the stored glucose so that the stored glucose will be reduced. In these circumstances there will be a muscle reaction in which the muscle will take up glucose in the blood so that glucose in the blood decreases and this can improve blood sugar control (Barnes, 2011).

\section{The correlation between anxiety and fasting blood sugar}

The result of the analysis is that there is a positive correlation between anxiety and fasting blood sugar. Patients with high anxiety will increase the value of fasting blood sugar. Anxiety level with fasting blood sugar $(b=2.78 ; \mathrm{p}<0.001)$.

People with DM generally experience anxiety about their current condi- tion. They will worry about high blood sugar level and complications that can occur, so that it will cause anxiety (SemiArdji, 2013). Management of the patient requires a lot of self-discipline and is considered able to cause stress. The appearance of these psychological symptoms can have a negative impact by influencing glycemic control (Luyckx et al, 2010). There was direct correlation between anxiety and glycemic control through physiological mechanisms (Hessler et al, 2014).

Anxiety disorders associated with hyperglycemia in people with DM. Anxiety causes the activation of the HPA axis and the sympathetic nervous system (Tsenkova et al, 2013). Activation of the sympathetic nervous system can cause flight or fight responses. The response occurs based on adrenaline (Anxiety care UK, 2014). This adrealin is released by the adrenal glands in the blood, causing an increase in the process of liver glycogen (glycogenolysis). Glycogen which has been obtained from the process of glycol-genolysis will then be converted into carbohydrates. These carbohydrates can enter the bloodstream, causing blood sugar level to increase (Mudjaddid, 2009).

\section{Correlation between chronic disease control club and fasting blood sugar}

Club activeness and decrease in fasting blood sugar. Patients who actively participated in the prolanis club program had low fasting blood sugar $(b=-30.14 ; p=$ 0.002).

Prolanis has 6 programs namely medical consultation, education, sms gate-away, home visit, club activities and monitoring the health status of patients.

Based on the results of previous studies, Prolanis in some areas is effective in reducing fasting blood sugar, HbA1c, and cholesterol levels in Diabetes Mellitus patients. But in its implementation, Pro- 
lanis has different obstacles - different in each region. Study that discusses how the Prolanis Program is carried out is still small so that makes researchers interested to know the role of the Prolanis Program in reducing fasting blood sugar levelon patients with DM at the Jatinangor Health Center (Utami, 2017).

\section{Correlation between DM compli- cations and fasting blood sugar}

From the results of the analysis, there is a positive correlation between DM complications and an increase in fasting blood sugar. Patients who get complications will increase blood sugar $(b=33.14 ; p=$ 0.009).

Diabetes mellitus is often referred to as the silent killer and often causes various complications for sufferers. Complications caused by diabetes mellitus can affect almost all organs of the body and can occur both acute and chronic. Complications of diabetes mellitus can occur due to poor blood sugar levels. In order to keep blood sugar levels under control, diabetes treatment and management is necessary. Strategies in treating and managing diabetes to achieve satisfactory blood sugar levels include conducting medical education, medical nutrition therapy and routine activities.

It is no less important in controlling diabetes mellitus is by checking blood sugar level regularly (Eliana, 2015).

Control of blood sugar levels for diabetics is important because with good blood sugar control, complications from diabetes can be prevented. However, from several studies conducted, it is known that most diabetics have uncontrolled blood sugar levels. Based on study conducted by DiabCare in Indonesia in 2006, the percentage of diabetics who had poor blood sugar levels was 47.2\%. Another study conducted at the Internal Medicine Polyclinic at Roemani Muhammadiyah
Hospital Semarang found that $46.3 \%$ of people with type 2 diabetes have poor blood sugar control. (Astuti and Setiarini, 2013).

\section{AUTHOR CONTRIBUTIONS}

Fajar Alam Putra collected data, examined the data, wrote the manuscript. Dono Indarto examined the conceptual framework and methodology, did data analysis, and interpreted the results of analysis. Ruben Dharmawan suggested the discussion materials.

\section{CONFLICT OF INTEREST}

We declared that there was no conflict of interest.

\section{ACKNOWLEDGEMENT}

The authors would like to thank the Head of Sukoharjo health center, Sukoharjo, Central Java for giving permission to run the data collection.

\section{REFERENCE \\ Anxiety Care UK (2014). The biological effects and consequences of anxiety. www.anxietycare.org.uk/the-biolo- gical-effects-and-consequences-of- anxiety. (RetrievedJune 24, 2019). Askes (Persero) (2012). Annual Report.}

Astuti CM, Setiarini A (2013). Faktorfaktor yang berhubungan dengan pengendalian kadar glukosa darah pasien diabetes melitus tipe 2 rawat jalan di poliklinik penyakit dalam RSJ Prof. Dr. Soerojo Magelang Tahun 2013. Jakarta.

Barnes E, Darryl (2012). Panduan untuk mengendalikan glukosa darah. Klaten: Insan Sejati.

Dinkes Jateng (2014). Penyakit tidak menular. Buletin jendela data dan informasi kesehatan Semester II.

Eliana F (2015). Penatalaksanaan DM sesuai konsensus perkeni 2015”. 
Journal of Health Promotion and Behavior (2019), 4(3): 137-144

https://doi.org/10.26911/thejhpb.2019.04.02.06

http://www.pdui-pusat.com/wpcontent/uploads/2015/12/SATELIT SIMPOSIUM-6.1-DM-UPDATEDAN-Hb1C-OLEH-DR.-Dr.FatimahEliana-SpPD-KEMD.pdf. (Akses 14 Juni 2019).

Hessler D, Fisher L, Glasgow R, Strycker L, Dickinson L, Arean P, Masharani U (2014). Reductions in regimen distress are associated with improved management and glycemic control over time. Diabetes Care. 37: 617-624.

IDF (2017). Global Guideline for Type 2 Diabetes

Ilyas EI (2011). Olahraga bagi Diabetesi. dalam: Soegondo, S., Soewondo, P., Subekti, I., Editor. Penatalaksanaan diabetes melitus terpadu bagi dokter maupun edukator diabetes. Jakarta: Fakultas Kedokteran Universitas Indonesia.

InfoAskes (2010). Pelayanan kesehatan berbasis dokter keluarga. Buletin; edisi Juni: 6-9

Kronenberg (2008). Williams Texbook of Endocrinology. Philadelphia: Saunder Elsevier Publishing.

Luyckx K, Krenke I, Hampson S (2010). Glycemic control, coping, and internalizing and externalizing symptoms in adolescent with type 1 diabetes. Diabetes Care. 33(7) : 1424-1429.
Mudjaddid E (2009). Dispepsia Fungsional. In: Sudoyo AW, Setiyohadi B, Alwi I, Simadibrata M, Setiati S, ed. Buku Ajar Ilmu Penyakit Dalam. Jilid III. Jakarta: Fakultas Kedokteran Universitas Indonesia.

Semiardji G (2013). Stres emosional pada penyandang diabetes. Dalam: Soegondo S, Soewondo P, Subekti I. PenatalaksanaanDiabetes Melitus Terpadu. Jakarta: FKUI.

Setiawan et al. (2014). Terhadap tekanan darah dan nadi pada lansia hipertensi, Prosiding Konferensi Nasional II PPNI Jawa Tengah, Semarang

Shaqina (2016). Hubungan keikutsertaan program jaminan kesehatan nasional (Jkn) dengan kepatuhan berobat penderita diabetes melitus tipe $2 \mathrm{di}$ Puskesmas Simpur Bandar Lampung. Fakultas Kedokteran, Universitas Lampung.

Tsenkova V, Albert M, Georgiades A, Ryff $C$ (2013). Trait anxiety and glucose metabolism in people without diabetes: Vulnerabilites among black women. Diabet Med. 24(6) : 803806.

WHO (2017). Noncommunicable diseases, Media Centre.

Zahtamal et al. (2007). Faktor resiko pasien diabetes melitus di RSUD Arifin Achmad Provinsi Riau. Journal of medicine science.1(1): 4 . 